\title{
Inactivation of Foodborne Viruses by UV Light: A Review
}

\author{
Vicente M. Gómez-López ${ }^{1}{ }^{\mathbb{D}}$, Eric Jubinville ${ }^{2}$, María Isabel Rodríguez-López ${ }^{3}$, Mathilde Trudel-Ferland ${ }^{2}$, \\ Simon Bouchard ${ }^{2}$ and Julie Jean ${ }^{2, *(D)}$ \\ 1 Catedra Alimentos para la Salud, Universidad Católica San Antonio de Murcia, Campus de los Jerónimos, \\ E-30107 Murcia, Spain; vmgomez@ucam.edu \\ 2 Institute of Nutraceuticals and Functional Foods, Département des Sciences des Aliments, Université Laval, \\ Québec, QC G1V 0A6, Canada; eric.jubinville.1@ulaval.ca (E.J.); mathilde.trudel-ferland.1@ulaval.ca (M.T.-F.); \\ simon.bouchard.13@ulaval.ca (S.B.) \\ 3 Departamento de Tecnología de la Alimentación y Nutrición, Universidad Católica San Antonio de Murcia, \\ Campus de los Jerónimos, E-30107 Murcia, Spain; mirodriguez@ucam.edu \\ * Correspondence: julie.jean@fsaa.ulaval.ca; Tel.: +1-418-656-2131 (ext. 413849)
}

check for updates

Citation: Gómez-López, V.M.; Jubinville, E.; Rodríguez-López, M.I.; Trudel-Ferland, M.; Bouchard, S.; Jean, J. Inactivation of Foodborne Viruses by UV Light: A Review. Foods 2021, 10, 3141. https://doi.org/ $10.3390 /$ foods10123141

Academic Editor: Marios Mataragas

Received: 3 November 2021

Accepted: 15 December 2021

Published: 18 December 2021

Publisher's Note: MDPI stays neutral with regard to jurisdictional claims in published maps and institutional affiliations.

Copyright: (c) 2021 by the authors. Licensee MDPI, Basel, Switzerland. This article is an open access article distributed under the terms and conditions of the Creative Commons Attribution (CC BY) license (https:/ / creativecommons.org/licenses/by/ $4.0 /)$.

\begin{abstract}
Viruses on some foods can be inactivated by exposure to ultraviolet (UV) light. This green technology has little impact on product quality and, thus, could be used to increase food safety. While its bactericidal effect has been studied extensively, little is known about the viricidal effect of UV on foods. The mechanism of viral inactivation by UV results mainly from an alteration of the genetic material (DNA or RNA) within the viral capsid and, to a lesser extent, by modifying major and minor viral proteins of the capsid. In this review, we examine the potential of UV treatment as a means of inactivating viruses on food processing surfaces and different foods. The most common foodborne viruses and their laboratory surrogates; further explanation on the inactivation mechanism and its efficacy in water, liquid foods, meat products, fruits, and vegetables; and the prospects for the commercial application of this technology are discussed. Lastly, we describe UV's limitations and legislation surrounding its use. Based on our review of the literature, viral inactivation in water seems to be particularly effective. While consistent inactivation through turbid liquid food or the entire surface of irregular food matrices is more challenging, some treatments on different food matrices seem promising.
\end{abstract}

Keywords: UV light; pulsed light; foodborne viruses; mechanism of inactivation; food safety

\section{Introduction}

Ultraviolet (UV) light refers to the portion of the electromagnetic spectrum that falls in the wavelength range of $100-400 \mathrm{~nm}$. This band is divided into vacuum UV (100-200 nm), UV-C (200-280 nm), UV-B (280-315 nm) and UV-A (315-400 nm). The range useful for inactivating viruses and microorganisms includes UV-C and UV-B up to about $300 \mathrm{~nm}$. The 100-200 nm sub-band can render viruses non-infectious, but only in a vacuum, since these wavelengths are readily absorbed by air.

Artificial UV light can be provided by lamps. The most common type is the lowpressure mercury lamp, which emits a quasi-monochromatic output at $253.7 \mathrm{~nm}$. Mediumpressure mercury lamps with polychromatic emission, light-emitting diodes that generate narrow bandwidth emissions in different ranges and excimer lamps containing a rare gas halide such as $\mathrm{KrCl}^{*}(222 \mathrm{~nm})$ or $\mathrm{XeBr}^{*}(282 \mathrm{~nm})$ are also available [1].

A special case of light-based disinfecting technology is pulsed light. These systems generate flashes of high-intensity polychromatic light ranging from UV to infrared by storing electric energy in capacitors, which are discharged to a xenon lamp [2]. Pulsed light can inactivate viruses faster than conventional light sources and is generally more efficient than low or medium pressure lamps on a time and fluence basis [3,4].

Viral inactivation by UV light is a function of the energy impinging on the targeted surface, called fluence $\left(F, \mathrm{~J} / \mathrm{cm}^{2}\right)$, defined formally as "the total radiant energy traversing 
a small transparent imaginary spherical target containing the point under consideration, divided by the cross section of this target" [5]. If the fluence rate $(E)$ is constant over time, the fluence is determined according to the following equation:

$$
F=E t
$$

where $t$ is the exposure time in seconds. For the specific case of pulsed light technology,

$$
F=F_{p} n
$$

where $F_{p}$ is the fluence per pulse and $n$ the number of pulses [6].

The use of UV light for water disinfection, including destruction of viruses, is a wellestablished industrial practice that has been in continuous use for more than 50 years [7] to process as much as 8.5 billion gallons of potable water per day [8]. The use of UV light to inactivate bacteria in foods has been studied extensively $[9,10]$, while its potential for inactivating viruses in or on foods has received less attention.

According to the latest World Health Organization (WHO) report on the subject, foodborne diseases are a significant global burden causing high rates of morbidity and mortality [11]. At least 31 foodborne agents, mainly microbial, often viral and sometimes chemical, caused an estimated 600 million illnesses in 2010 [11]. In addition to disastrous consequences for public health, contamination of food by viruses remains a significant economic issue for stakeholders in the food industry, where recall costs and drops in sales can be financially ruinous [12]. In the United States and Canada, more than 20 recalls due to foodborne viruses were issued from 2017 to 2021, specifically for frozen berries and shellfish [13-15]. Despite the prevalence of foodborne viral illness, interest in this domain has emerged relatively recently. It was not until 2008 that the Food and Agriculture Organization (FAO) in collaboration with the WHO concluded that viruses were causing an increasing proportion of foodborne infectious intestinal diseases. The scarcity of epidemiological data, the difficulty of detection, persistence on food contact surfaces and limited post-harvest decontamination options were all identified as contributors to the emerging problem. Two viruses stood out for their number of cases and the severity of their symptoms: human noroviruses (HuNoV) and hepatitis A virus (HAV) [16]. It is estimated that the number of foodborne illnesses caused by HuNoV annually has passed 124 million cases with 34,000 deaths worldwide [11]. HuNoV appears to be causing $58 \%$ of foodborne illnesses in the USA [17] and 64\% in Europe and the British Isles [18]. For HAV, the number of foodborne cases is smaller (14 million worldwide), but the mortality rate is 10 times higher (28,000 per year) and its incidence is increasing at a worrying pace in and around Europe $[11,19]$. HAV is transmitted via various routes starting from feces, including contaminated irrigation water, fishing sites or infected food handlers (symptomatic or not) [20-22]. Ready-to-eat and minimally processed foods such as shellfish, vegetables, and fruits are often implicated in HuNoV and HAV outbreaks [16]. During the past decade, berries, particularly frozen, have been at the origin of several major outbreaks of both viruses around the world $[23,24]$, including one of the largest outbreaks ever of $\mathrm{HuNoV}$ ( $>11,000$ cases), which occurred in Germany in 2012, believed to be caused by strawberries from China [25]. In 2013, frozen berries were the source of a large and prolonged multistate European outbreak of HAV centralized in Italy with more than 1800 cases [26,27]. Green onions were the source of an outbreak of HAV that led to 601 cases and 3 deaths in the United States in 2003 [28]. The mollusc origin of several epidemics around the world has shown the significance of contaminated water as a vector of HuNoV [29-31] and HAV [32,33]. Involvement of food handlers served in public is also reported frequently $[19,34]$. In recent years, public health authorities have noted an increase in cases of hepatitis E virus (HEV), an emerging foodborne virus, particularly in countries with high standards of hygiene [35,36]. Compared to HuNoV and HAV, outbreaks of HEV tend to be small and isolated [19]. HEV has been found in seafood [37-40], fresh and frozen produce [40-42] and, more recently, in the milk of different animals [43,44]. However, pork 
and game such as wild boar and deer are the sources most often implicated in foodborne cases $[19,45]$. Although HEV is the most common hepatitis virus associated with meat products, HAV has been detected in processed and raw meats in South America [46] and 117 cases of $\mathrm{HuNoV}$ were traced to an infected handler employed in the production of a ready-to-eat meat product [47].

In this review, we examine inactivation of the most important foodborne viruses and their laboratory surrogates by UV light and discuss the commercial applicability of this technology to specific food types and food contact surfaces.

\section{Definition of Viruses}

Viruses are lifeforms that have their genome (single-stranded or double-stranded DNA or RNA) coiled with a protein into a structure called a nucleocapsid, which may be enveloped in a lipid membrane [48]. They are classified phylogenetically in orders, families and genera defined by their most salient taxonomic characteristics [49]. Most virions (single infectious viral particles) have an icosahedral or helical structure [50] with or without external features such as spike proteins [51]. Some have a segmented genome [52]. The length of the genome ranges from 1682 nucleotides (Hepatitis delta virus) to 2,473,870 nucleotides (Pandoravirus salinus) [53]. The average length of foodborne virus genomes is about 7500 nucleotides. Virions range in size from about $17 \mathrm{~nm}$ to $1.5 \mu \mathrm{m}$ in average diameter [54]. Viruses are obligate intracellular parasites, their life cycle consisting of infecting cells of the host, replicating therein, emerging therefrom and infecting other cells or being transmitted to a new host [55]. Nearly all living organisms, including mammals, birds, reptiles, amphibians, fish, bacteria, archaea, and plants, can be infected by viruses. Many viruses can be propagated in suitably adapted cell cultures [56,57].

Each virus infects a limited range of host species and tissue or cell types. The surface structures of a virus allow it to attach to specific cell receptors composed of proteins, carbohydrates and/or lipids [58]. For example, norovirus (NoV) has two surface proteins, VP1 and VP2, that recognize cells in the human digestive tract [59]. After attachment, the viral genome is released from the capsid into the cell by direct fusion or receptormediated endocytosis. The invading DNA or RNA then commandeers the cell cytoplasm or nucleus to direct the synthesis of genome replicates and new viral proteins using host cell ribosomes [60]. The assembled new virions then emerge from the infected cell, in some cases causing cell lysis [61].

Viruses in general and particularly foodborne viruses are tenacious because of their ability to persist in the environment, their adhesive properties and the low infectious titer required for pathogenicity. Some viruses remain infectious over a wide range of $\mathrm{pH}$, temperature and humidity and tolerate freezing and various physical and chemical treatments [62]. Non-enveloped viruses (e.g., foodborne) are more resistant than enveloped types [63], the lipid membrane being less stable than the capsid. Detergents are very effective at preventing infection by most enveloped viruses [63]. Adhesion to surfaces is a major facilitator of viral propagation. This factor depends mainly on electrostatic and hydrophobic forces, which are influenced by environmental conditions such as ionic strength, $\mathrm{pH}$, and the presence or absence of surfactant substances [64]. Over the past decade, viruses have become a major food safety concern.

\section{The Most Relevant Foodborne Viruses}

\subsection{Human Noroviruses}

Human noroviruses belong to the Caliciviridae family, which are non-enveloped viruses with a positive-stranded RNA genome of approximately 7.5-7.7 kilobases [65]. Their impressive genetic diversity comprises more than 10 genogroups (GI to GX) currently represented by 48 genotypes [66]. Only a few specific genotypes, namely GI, GII, GIV, GVIII and GIX, are known to affect humans [67]. The only variant known to be prevalent worldwide is GII.4 [68,69], although recent data show that GII.17 has become an emergent dominant strain [70]. In China, GII has been found to be nine times more prevalent than 
GI [71]. Much work has been devoted to developing an immunization tool. However, no $\mathrm{HuNoV}$ vaccine is currently beyond phase 2 clinical trials [72-75]. Vaccine developers face the challenge of a high mutation rate [76]. In addition, since the infectious dose of $\mathrm{HuNoV}$ is 10-100 virions [77], controlling the spread of this virus will likely continue to rely heavily on inactivation strategies applied in the environment.

\subsection{Hepatitis A Virus}

HAV are quasi-enveloped viruses belonging to the Picornaviridae family [78]. They have a single-stranded positive-sense genome approximately $7.5 \mathrm{~kb}$ in length [79-81]. Unlike HuNoV, the number of genotypes is small (6), and only three affect humans (I, II, and III). These are divided into subtypes A and B [82]. Genotype I is the most prevalent [36]. With only one circulating serotype [83], the development of an effective vaccine was relatively easy [84-86]. Distinguishable strains circulate variably in different countries [87]. HAV epidemiology appears to differ considerably between industrialized and developing countries [88]. Due to vaccination, HAV circulates much less in developed countries. However, the younger population may have never been exposed to HAV or vaccinated, making them potentially susceptible to infection [36]. Since most outbreaks of HAV in developed countries originate from developing countries [89], due mainly to increased importation of produce [90], improvements in global sanitary standards and viral control methods are needed to limit the re-emergence of HAV where it is not endemic.

\subsection{Hepatitis E Virus}

An emerging cause of foodborne hepatitis is the E virus [36]. HEV is a quasi-enveloped virus belonging to the Hepatoviridae family [91]. It is a positive-stranded RNA virus with a genome size of $7.2 \mathrm{~kb}$ [91]. Eight genotypes are known. Only HEV1 and HEV2 are obligate human pathogens, while HEV3 and HEV4 are zoonotic [91]. An increasing body of evidence suggests that transmission of $\mathrm{HEV}$ as a foodborne pathogen is frequently zoonotic [91-94]. Although the presence of HEV seems to be higher in Europe than in the Americas, a recent meta-analysis suggests that the continents have nearly equal HEV seroprevalence [95]. Although this emerging foodborne virus is gaining ground, means of controlling it by inactivation remain scarce. The knowledge acquired in the quest to control HAV might shed light on the vulnerabilities of this new pathogen.

\subsection{Laboratory Surrogates Used to Study Foodborne Viruses}

The study of human norovirus genotypes has been slowed by limited access to (1) HuNoV-positive samples (feces and vomitus), (2) adequate biosafety containment (level 2), and (3) cell culture techniques that work on more than a few HuNoV genotypes. These obstacles have been overcome somewhat by using a variety of proxy viruses. Among these are murine norovirus 1 (MNV-1), Tulane virus (TV), feline calicivirus (FCV) and a few bacteriophages (e.g., MS2 and $\varphi$ X174) [96]. Some of these surrogates are phylogenetically closely related to HuNoV. For example, MNV-1, a genogroup V norovirus that only infects mice, has been found to be suitable as a surrogate in heat inactivation studies [97]. These substitutes exhibit key characteristics of $\mathrm{HuNoV}$, such as persisting under conditions of extreme $\mathrm{pH}$, humidity, and temperature for several days or months [98-100]. However, in terms of affinity, adhesion, and attachment, only TV has been shown to share several binding receptors with $\mathrm{HuNoV}$ [101-103], making it preferred in foodborne virus inactivation studies. The choice of a proxy virus must be reasoned, and caution must be exercised when extrapolating results directly to HuNoV. The development of an easy and accessible culture tools allowing the study of all HuNoV genotypes would definitely be ground-breaking.

\subsection{Other Important Foodborne Viruses}

Several other viruses have been implicated in outbreaks of illness involving the same food matrices as for $\mathrm{HuNoV}$ and hepatitis. These include rotaviruses, adenoviruses, astroviruses, parvoviruses, polioviruses, influenza, and other common cold or flu viruses [104,105]. 
The Aichi virus is also emerging as an important foodborne virus in several parts of the world [106,107]. Indirect contamination of food by viruses such as herpes simplex virus 1 (HSV-1) cannot be ruled out [108]. While these viruses are much less prevalent than $\mathrm{HuNoV}$ or the hepatitis viruses, viral control strategies should be adapted to inactivate them as well. In the current repertoire of viral inactivation methods, treatment with UV has been proving its effectiveness for a long time.

\section{Mechanism of Viral Inactivation by UV, and Genome Repair Mechanisms}

\subsection{Generalities Regarding Inactivation by UV}

UV has been used widely for more than a century to suppress microbial proliferation [109] in biological safety cabinets in research and medical laboratories [110], in water treatment facilities [111], hospitals [112], ambient bioaerosols [113], processing equipment in food industries [114,115], and in many other situations. Furthermore, continuous UV treatment as simple as the sunlight [116] or more complex designs, such as pulsed light machines [117] are amongst the vast possibilities of developed light sources [118-122] to control microorganisms. Although its effectiveness was discovered long ago, little has been added to its basic principle in our ongoing fights against pandemics [123] other than new designs such as UV-blasting robots [124]. The vast work in the field of UV disinfection ultimately led to the discovery of its antimicrobial mechanism of action, a key step toward viral control.

\subsection{Nucleic Acid}

Studies of the mode of action by which UV suppresses microbial proliferation have focused mainly on bacterial growth [125]. Briefly, UV photons have enough energy to break and form chemical bonds, causing, for example, dimer formation between consecutive bases in DNA or RNA [126]. Uracil, cytosine, thymine, and adenine may react, and the resulting damage may interfere with key functions such as genomic transcription and replication, leading ultimately to cell death [126]. Fortunately, most of the lethal mechanisms described for bacteria also affect viruses.

It is known that the genetic material within the viral capsid is a strong absorber of UV radiation [116], especially close to $254 \mathrm{~nm}$, while other viral components such as proteins are minor absorbers [127]. UV is effective against both RNA viruses and DNA viruses, and sensitivity to UV is correlated strongly with genome length [116]. Pyrimidine dimers and particularly thymine dimers are the principal lethal photoproducts [128], and DNA viruses are, therefore, more sensitive than RNA viruses [127,129]. This is an important point in the food context, since the most problematic viruses have RNA genomes. Additionally, single-stranded DNA or RNA is more sensitive than double-stranded [130].

It has been shown with mengovirus that in addition to forming DNA or RNA dimers, UV can also destabilize and degrade the capsid and form covalent bonds between proteins and RNA [131], thus rendering the virus non-infectious [132]. This is important because the mechanism of action of UV seems to depend somewhat on the wavelength used. At $254 \mathrm{~nm}$, the genome is targeted [133], whereas lower wavelengths (207-222 nm) appear to damage surface proteins that are essential for binding to host cells [123,134]. UV-C at $254 \mathrm{~nm}$ has been found not to damage the SARS-CoV-2 spike protein, nucleocapsid protein or virion morphology, while damaging the genome [135]. Furthermore, one study has also shown a significant loss of spike protein function following exposure to UV-A at about $343 \mathrm{~nm}$ [136]. This apparent relationship between exposure wavelength and potential for damaging viral proteins may be relevant to disinfection strategy.

\subsection{Protein Damage}

Although protein damage by UV plays a minor role in viral inactivation, no doubt remains about its occurrence $[137,138]$. Electron microscopy reveals structural modifications of major and minor proteins of the adenovirus capsid after low-intensity and mediumintensity UV treatments [137,139]. A similar effect has been observed after pulsed light 
treatment of MNV-1 [140]. These results all confirm UV as an important tool for controlling foodborne viruses based on damaging genetic material and key proteins. Another key component of viral inactivation by UV is the ability or inability of virions to repair damage inflicted on their genome.

\subsection{Host Repair Mechanisms}

While host repair mechanisms are beyond the scope of this review, it should be noted that photolyase can bind dimers, absorb energy, and use electron transfer to split dimers into their original DNA form [141]. The only virus known to possess such an enzyme is the fowl pox virus, a poultry pathogen [142]. UV, therefore, remains an effective antiviral disinfectant in food settings (surfaces and/or produces), notwithstanding the possibility of viral genome restoration by host photolyase.

\section{Impact of UV Treatment on Foods and Food-Related Matrices (Liquids and Surfaces)}

\subsection{Non-Food Liquids}

Water is relatively easy to disinfect with UV since it does not absorb light and can be mixed to ensure equal exposure of suspended particles including viruses. Transparent liquids such as phosphate-buffered saline, of which the absorbance in the 200-1100 range is close to zero, are therefore preferred for in vitro tests [143]. The amount of information available on the use of UV light to disinfect water is considerable. Indeed, phage MS2 is used for UV reactor validation in North America [133]. A classic review article on this subject was published in 2006 by Hijnen et al. [144] and comprehensive kinetic data were published in 2009 by Kowalski [111].

Pulsed light is a more recent technology and, therefore, less is known about its effectiveness for water disinfection. The first published account of its use for inactivation of viruses, including some foodborne, appears to be that of Roberts and Hope (2003), who obtained at least $4.8 \mathrm{log}$ reductions in HSV-1, HAV, poliovirus 1, canine parvovirus, bovine parvovirus and non-foodborne viruses (Sindbis, vaccinia, encephalomyocarditis and Simian virus 40 ) with only two pulses of $1 \mathrm{~J} / \mathrm{cm}^{2}$ each for less than $1 \mathrm{~s}$ of treatment time [117]. Lamont et al. (2007) later obtained 4 log reductions in poliovirus $1 \mathrm{a}$ and Group D adenovirus infectiousness in PBS, Jean et al. (2011) at least 4 log reductions in MNV-1 and HAV in PBS and Huang et al. (2017) at least 5 log reductions in MNV-1 and TV in PBS $[143,145,146]$. Inactivation was significantly less in PBS containing dissolved protein $[117,143]$, which absorbs in the UV range. Table 1 summarizes the different viral inactivation results obtained using pulsed light (Table 1).

Table 1. Inactivation of viruses by pulsed light.

\begin{tabular}{ccccc}
\hline Virus & Matrix & Fluence $\mathbf{( J / \mathbf { c m } ^ { 2 } )}$ & $\begin{array}{c}\text { Log } \\
\text { Inactivation }\end{array}$ & References \\
\hline Adenovirus & PBS & 5.6 & 4.0 & [145] \\
\hline Bovine parvovirus & PBS & 1.0 & 4.3 & [117] \\
\hline Canine parvovirus & PBS & 1.0 & $>6.5$ & {$[117]$} \\
\hline Encephalomyocarditis & PBS & 1.0 & $>5.9$ & {$[117]$} \\
\hline & Black pepper & 9.4 & 0.64 & {$[147]$} \\
& Garlic & 18.8 & 0.40 & \\
Escherichia coli phage & Chopped mint & 18.8 & 1.28 & \\
MS2 & Glass beads & 9.4 & 4.87 & \\
& PBS & 3.8 & 1.6 & \\
& Swine liver & 60 & 0.97 & \\
& Ham & 60 & 1.3 & \\
\hline
\end{tabular}


Table 1. Cont.

\begin{tabular}{|c|c|c|c|c|}
\hline Virus & Matrix & Fluence $\left(\mathrm{J} / \mathrm{cm}^{2}\right)$ & $\underset{\text { Log }}{\text { Inactivation }}$ & References \\
\hline \multirow{4}{*}{ HAV } & PBS & & $>5.7$ & [117] \\
\hline & PBS & 0.05 & 4.8 & [143] \\
\hline & Stainless steel & 0.06 & 5 & \\
\hline & PVC & 0.091 & 5 & \\
\hline HSV-1 & PBS & 1.0 & $>4.8$ & [117] \\
\hline \multirow{14}{*}{ MNV-1 } & Strawberry & 1.27 & 1.8 & [149] \\
\hline & Raspberries & 1.27 & 3.6 & \\
\hline & PVC & 2.07 & 3 & [140] \\
\hline & Blueberry & 22.5 & 3.8 & [146] \\
\hline & Strawberry & 22.5 & 0.9 & \\
\hline & PBS & 2.47 & 5.8 & \\
\hline & PBS & 0.06 & 5.0 & [143] \\
\hline & PVC & & 5 & \\
\hline & Stainless steel & 0.06 & 5 & \\
\hline & PBS & 2.07 & 3.3 & [140] \\
\hline & Alginate & 0.69 & 3.6 & \\
\hline & Hard water & 4.84 & 3.9 & \\
\hline & Turbid water & 3.45 & 3 & \\
\hline & Stainless steel & 8.98 & 2.6 & \\
\hline \multirow{3}{*}{ Phage $\varphi$ X174 } & Swine Liver & 60 & 2 & \\
\hline & Ham & 60 & 1.6 & [148] \\
\hline & Sausage & 60 & 1.6 & \\
\hline \multirow{2}{*}{ Poliovirus } & \multirow{2}{*}{ PBS } & 0.28 & 4.0 & [145] \\
\hline & & 1 & $>6.7$ & [117] \\
\hline Simian virus 40 & PBS & 1.0 & 3.7 & [117] \\
\hline Sindbis & PBS & 1.0 & 7.2 & [117] \\
\hline $\mathrm{TV}$ & PBS & 4.94 & 6 & {$[146]$} \\
\hline Vaccinia & PBS & 1.0 & $>5.1$ & [117] \\
\hline
\end{tabular}

\subsection{Liquid Foods}

The inactivation of viruses in liquid foods has been studied using coconut water $[150,151]$ and skim milk $[152,153]$ challenged with phages MS2 and T1UV in two types of experimental set-up: collimated beam in a stirred batch reactor and a Dean vortex continuous reactor. Reductions in viral titer reached 4 log cycles for MS2 and more than $5 \log$ for T1UV in coconut water $[150,151]$ and at least $5 \log$ for both MS2 and T1UV in skim milk [152,153]. It is widely known that the efficacy of UV treatments of liquid foods decreases with turbidity and suspended solids, which absorb or scatter the light before reaching the viral particles. However, this limitation can be overcome by reactor designs that promote turbulent flow to maximize the exposure of any virus present. In the above cases, UV transmittances as low as $9.7 \% / \mathrm{cm}$ in coconut water and $0.57-0.89 \% / \mathrm{cm}$ in skim milk were sufficient. The formation of potentially toxic compounds due to the action of UV light on food components was also examined. No cytotoxicity was observed when skim milk was treated with up to $0.17 \mathrm{~J} / \mathrm{cm}^{2}$ [153] or coconut water with up to $0.4 \mathrm{~J} / \mathrm{cm}^{2}$ [151], fluences that were high enough to reduce viral titers substantially.

\subsection{Meat Products}

The use of UV light as a single method for viral inactivation in meat products is possible, although results are modest. This is likely because the irregular surface shields viral particles from exposure and because meat proteins can absorb part of the illumination [154]. For example, only 1.23 and 1.17 log reductions in MNV-1 and HAV, respectively, were 
obtained on fresh chicken breast. The inactivation curve in both cases progressed without tailing, suggesting that higher fluences (up to $3.6 \mathrm{~J} / \mathrm{cm}^{2}$ ) could increase inactivation. However, the sensory quality of the chicken meat was decreased at fluences above $1.2 \mathrm{~J} / \mathrm{cm}^{2}$, at which only $0.5 \log$ reductions were observed for both viruses. UV-C treatment combined with another decontamination technique would likely give better results [155]. A still modest but higher inactivation of FCV and Escherichia coli coliphages MS2 and $\varphi$ X174 (0.97-2.8 log reduction) was observed on pork liver, ham and sausage treated by pulsed light at fluences of $45-60 \mathrm{~J} / \mathrm{cm}^{2}$ [148].

\subsection{Fruits and Vegetables}

Berries are delicate products very susceptible to damage and are usually just washed in tap water or chlorinated water during processing. These processes are insufficient to eliminate human pathogens that may be present. HAV and NoV have been implicated in numerous outbreaks related to fresh and frozen berries [116]. Decontamination of fresh and frozen strawberries, blueberries, and raspberries spiked with HAV and MNV-1 has been attempted (Table 2).

Table 2. Inactivation of viruses on fruits or vegetables by UV-C.

\begin{tabular}{|c|c|c|c|c|}
\hline Virus & Substrate & $\begin{array}{l}\text { Fluence }\left(\mathrm{J} / \mathrm{cm}^{2}\right) \\
\text { for } 1 \log \\
\text { Reduction }\end{array}$ & $\begin{array}{l}\text { Fluence }\left(\mathrm{J} / \mathrm{cm}^{2}\right) \\
\text { for } 5 \log \\
\text { Reduction }\end{array}$ & References \\
\hline Adenovirus type 41 & Green onions & & $0.240(3 \log )^{*}$ & [156] \\
\hline \multirow{3}{*}{ Aichi virus } & Romaine lettuce & & \multirow{3}{*}{$\begin{array}{l}0.240 \\
0.240(3.66 \log ) *\end{array}$} & [157] \\
\hline & Green onions & & & \\
\hline & Strawberries & 0.240 & & \\
\hline \multirow[t]{3}{*}{ FCV } & Romaine lettuce & & \multirow{3}{*}{$\begin{array}{l}0.240 \\
0.240(3.92 \operatorname{logs}) \text { * }\end{array}$} & \\
\hline & Green onions & & & \\
\hline & Strawberries & $0.240(2.28 \log )^{*}$ & & \\
\hline \multirow{10}{*}{ HAV } & \multirow{2}{*}{$\begin{array}{l}\text { Frozen } \\
\text { strawberries }\end{array}$} & 0.212 & & [116] \\
\hline & & 0.13 & & [158] \\
\hline & $\begin{array}{l}\text { Frozen } \\
\text { blueberries }\end{array}$ & 0.212 & & [116] \\
\hline & \multirow{2}{*}{$\begin{array}{l}\text { Fresh } \\
\text { strawberries }\end{array}$} & 0.212 & & \\
\hline & & $0.240(2.60 \log )^{*}$ & & [157] \\
\hline & $\begin{array}{l}\text { Fresh } \\
\text { blueberries }\end{array}$ & 0.212 & & \\
\hline & $\begin{array}{l}\text { Fresh } \\
\text { raspberries }\end{array}$ & 0.212 & & [159] \\
\hline & Romaine lettuce & & 0.240 & [157] \\
\hline & Green onions & & 0.240 & \\
\hline & & & 0.240 & [156] \\
\hline \multirow{4}{*}{ MNV-1 } & Fresh blueberry & 1.331 & \multirow{4}{*}{$\begin{array}{l}1.2 \\
\text { (Water-assisted) }\end{array}$} & [116] \\
\hline & Fresh blueberry & 1.2 (Dry) & & [160] \\
\hline & Green onions & $\begin{array}{l}0.24 \\
0.6\end{array}$ & & [156] \\
\hline & Lettuce & 0.6 & & [161] \\
\hline Phage MS2 & Iceberg Lettuce & 0.019 & & [162] \\
\hline
\end{tabular}

${ }^{*}$ In parentheses: the reduction reached when differing from 1 log or $5 \log$.

Even though UV-C was able to reduce viral titers on berry surfaces by up to 3 log cycles in some cases, its efficacy was limited and prolonging the treatment beyond $1.3 \mathrm{~J} / \mathrm{cm}^{2} \mathrm{did}$ not improve inactivation. Shielding by the irregular surface of berries is the likely cause of this, despite the UV reactor being designed with mirror-finish reflectors on all sides to 
maximize exposure. UV-C might nevertheless be effective on berries as part of a hurdle approach, since it has only a mild effect on fruit sensory quality and does not produce the toxic by-product furan [116]. The irregular surface of strawberries was a major obstacle for viral inactivation [157], which ranged from 1.9 to $2.6 \log$ TCID5 $/ \mathrm{mL}$ for FCV, HAV and Aichi virus, several log cycles lower than achieved on foods with smoother surfaces such as lettuce and green onions.

Pulsed light has been tested in a process by which berries are suspended in agitated water to avoid heating and facilitate berry movement and rotation and thereby allow more uniform exposure. Log reductions of 1.8 and 3.6 in MNV-1 titer were obtained for strawberry and raspberry, respectively [149], which were significantly higher than the inactivation obtained after immersion for an equivalent time $(1 \mathrm{~min})$ in water containing $10 \mathrm{ppm}$ chlorine. As in the case of UV-C light [116], inactivation was greater on smoothersurfaced fruit (raspberry) than on strawberry. Furthermore, the higher efficacy of this waterassisted treatment versus chlorinated water suggests using this method as an alternative to chlorine, which can generate harmful by-products such as trihalomethanes.

Different research groups have tried to implement UV-C treatments to increase the safety of another product that is consumed fresh, namely lettuce. The efficacy of UV-C in this case is high, at least $4 \log \mathrm{TCID}_{50} / \mathrm{mL}$ for HAV, Aichi virus and FCV on Romaine lettuce [157] but not for phage MS2 on Iceberg lettuce [162]. In all cases, inactivation was initially rapid then tailed off. A low level of inactivation was also observed for MNV-1 [161] but with a log-linear decline.

Green onions may or may not be disinfected depending on the type of virus. High levels of inactivation $\left(>5 \log \mathrm{TCID}_{50} / \mathrm{mL}\right)$ have been reported for HAV [156,157], but not for FCV, Aichi virus [157], human adenovirus type 41 and MNV-1 [156], in decreasing order of inactivation. Inactivation was negligible when viruses were internalized, which can occur during hydroponic growing by uptake through roots. These results are to be expected since UV-C is a superficial treatment.

\subsection{Other Food Types}

Viruses are very stable in low-moisture foods. UV-C light applied in combination with ozone and hydrogen peroxide vapor can inactivate practically $100 \%(4 \log )$ of FCV and MNV in chocolate, but only $1 \log$ in pistachios and $<1 \log$ in cornflakes [163]. Table 3 lists the inactivation of different viruses on foods other than vegetables by conventional UV-C light (Table 3). The efficacy of pulsed light has also been tested using MS2 virus on black pepper, garlic and chopped mint, but the titer was reduced by only $1.28 \log$ in the best case [147].

Table 3. Inactivation of viruses by UV-C on foods other than vegetables.

\begin{tabular}{ccccc}
\hline Virus & Substrate & $\begin{array}{c}\text { Fluence }\left(\mathbf{J} / \mathbf{c m}^{2}\right) \\
\text { for } \mathbf{~ l o g} \\
\text { Reduction }\end{array}$ & $\begin{array}{c}\text { Fluence }\left(\mathbf{J} / \mathbf{c m}^{2}\right) \\
\text { for } \mathbf{5} \mathbf{l o g} \\
\text { Reduction }\end{array}$ & References \\
\hline FCV & $\begin{array}{c}\text { Chocolate } \\
\text { Pistachios }\end{array}$ & $3.8(2 \log )^{*}$ & $3.8(4 \log )^{*}$ & {$[163]$} \\
& Cornflakes & 3.8 & & \\
\hline HAV & Fresh chicken & & & \\
breast & 3.6 & & \\
& Stainless steel & 0.3 & \\
surface & $3.8(2 \operatorname{logs})^{*}$ & & \\
& Chocolate & 3.8 & & \\
& Pistachios & 3.8 & & \\
\hline
\end{tabular}


Table 3. Cont.

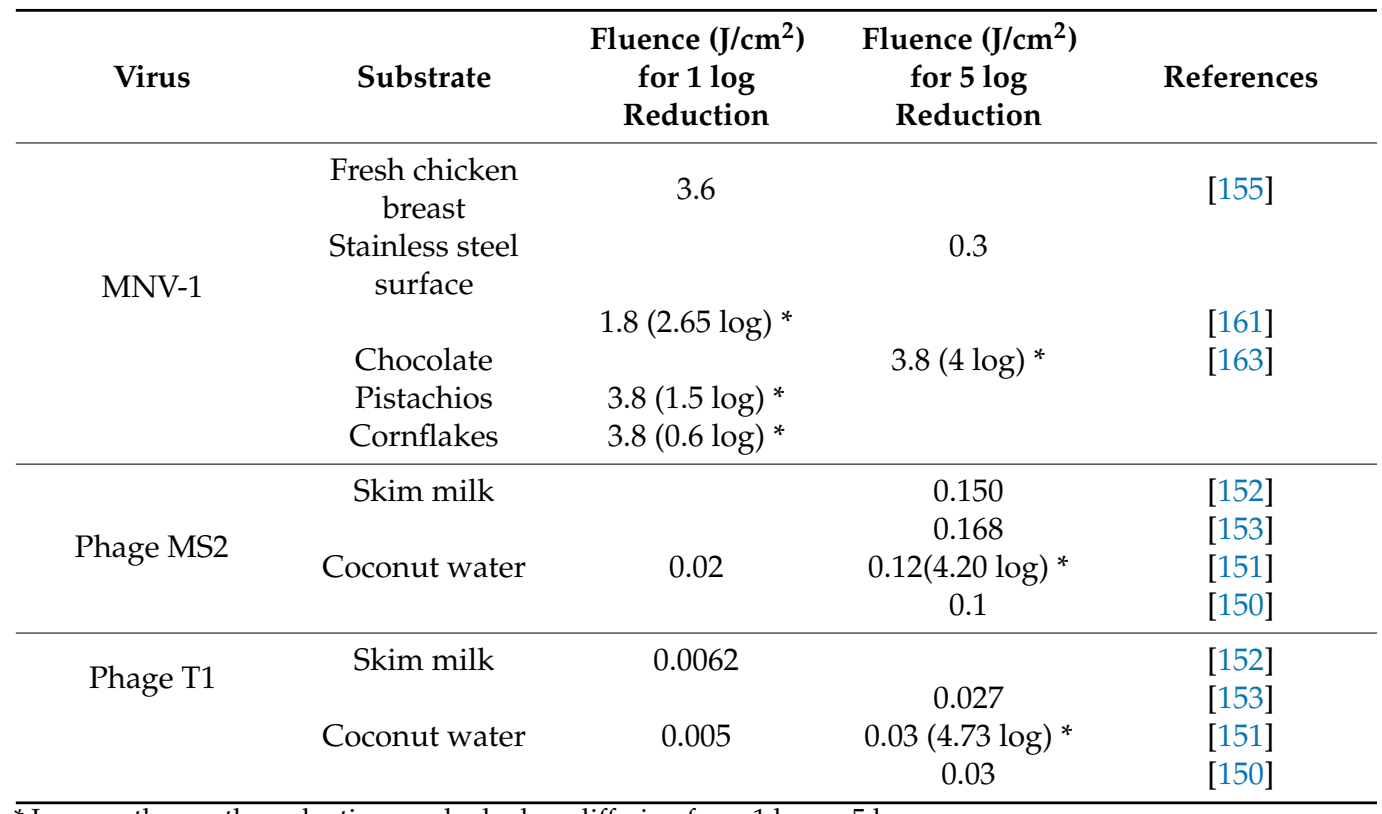

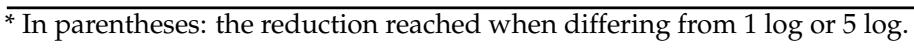

\subsection{Food Contact Surfaces}

The virucidal efficacy of UV light on food contact surfaces has been tested using stainless steel and different types of plastics. Inactivation is theoretically favored on stainless steel because of the low degree of shielding, and was significant using UV-C, $4.4 \log$ for MNV-1 and $2.6 \log$ for HAV [159]. Both inactivation curves exhibited tailing, indicating that extending the exposure time would not increase inactivation proportionately. On the other hand, inactivation was completed when using pulsed light (5 log reductions) on stainless steel and PVC [143]. Using MNV-1 also, Vimont et al. (2015) observed reductions of 3.8 to $4.3 \mathrm{log}$ on high-density polyethylene and stainless steel and total inactivation on PVC [140]. Both studies found that viral inactivation is decreased by several orders of magnitude when the surfaces are fouled.

\section{Limitations of UV Treatment}

Over the years, several limitations of UV as a sanitizing agent have been identified, such as its low penetrating power, the shadowing effect, its reduced efficacy in the presence of extraneous organic matter and the multiplicity of reactivation. Its penetrating power is low on materials such as fruit skins [164] and water [165], allowing many microorganisms to go unexposed. The penetration depth on food surfaces ranges from $6 \mu \mathrm{m}$ to $2.2 \mathrm{~mm}$, making UV unreliable for disinfecting porous food matrices [164]. The shadowing effect of rough or convoluted surfaces can be overcome somewhat using rotating lamps to illuminate from all possible angles. Berries with cavities, bivalve shellfish, and pork liver are examples of problematic foods. The presence of extraneous organic matter also has been shown to reduce the effectiveness of photon energy treatments by presenting an additional obstacle to illumination of food surfaces that may harbor viruses [166,167]. When possible, delicate washing of the matrix would help by removing at least some of this organic matter. Lastly, UV treatment should be expected to induce alterations (mutations) of the viral genome. If several damaged virions were to invade the same host cell, genome reassortment could allow a productive infection to occur with generation of a new strain $[168,169]$. This is called multiplicity of reactivation and has been described as a survival mechanism for foodborne viruses $[170,171]$. 


\section{Legislation}

The use of UV light in foods is regulated by different legislations, and in some countries, the approach used differs. While the USA regulates the use of the technology as such, other countries consider UV-treated foods as novel foods and legislate case by case. In these regulations, the use of UV light is considered not only due to its antimicrobial efficacy but also for other intended uses, such as the photogeneration of vitamin D. Some countries also differentiate their regulations depending on the type of light source and if there is no intended use for virus inactivation.

In the USA, conventional light sources and pulsed light technology have their own regulations. The use of low-pressure mercury lamps for food treatment is limited under regulation 21CFR179.39, which differentiates its use for surface microorganism control in food and food products, sterilization of water used in food production and reducing human pathogens and other microorganisms in fruit juices [172]. In this case, the US Food and Drug Administration does not specify fluence values but concluded that this should be achieved for individual usage situations in a manner consistent with good manufacturing practice [173]. The application of pulsed light technology to foods is regulated by the 21CFR179.41 [174], setting restrictions such as a maximum fluence of $12 \mathrm{~J} / \mathrm{cm}^{2}$. The use of UV light for treating baker's yeast with the purpose of synthetizing vitamin D2 is regulated by the 21CFR172.381 [175].

In the European Union, UV-light-treated foods are considered novel foods. The intended use is for the generation of vitamin $\mathrm{D}$ and it is noteworthy that the wavelength ranges differ for each case: $200-800 \mathrm{~nm}$ for mushrooms, not specified for baker's yeast, 240-315 nm for bread and 200-310 nm for milk [176].

Canada allows the use of UV light using the CiderSure 3500 Ultraviolet (UV) light unit for treating unpasteurized and unfermented apple juice and cider products, implementation of which is aimed to inactivate Escherichia coli O157:H7 [177]. In India, raw milk treated with a Sure-Pure UV system has the status of "Process Approval" [173].

\section{Conclusions and Future Trends}

Published results on viral inactivation by UV light and pulsed or otherwise are consistent with what would normally be expected. UV light is a highly efficient virucide (directly altering the genetic material of viruses and modifying the composition of viral proteins) for transparent liquids and even opaque liquids if turbulent flow is maintained. On solid foods, surface irregularity limits inactivation. The limited amount of information available and the high variability in the response of different types of viruses to UV light preclude reaching any definitive conclusions about the commercial applicability of this technology. UV-C is somewhat less effective on meat, berries, and dry herbs. However, it may be combined with other technologies as part of a hurdle approach to achieve better results. The agitated-water-assisted UV treatment appears to be more effective than just rinsing with chlorinated water for disinfecting berries and deserves further exploration. Inactivation kinetics are, in some cases, log-linear and in others logarithmic followed by tailing. In the former case, higher fluences might yield better results for some virusfood pairs. UV can also be useful for food-contact surface decontamination. Acquiring additional knowledge on the impact of UV light on foodborne viruses and their laboratory surrogates remains a key process in our advancement towards better understanding of food safety and improving the future security of food industries and their customers.

Author Contributions: Conceptualization, V.M.G.-L. and J.J.; supervision, V.M.G.-L. and J.J.; writingoriginal draft preparation, E.J., M.T.-F., S.B., J.J., M.I.R.-L. and V.M.G.-L.; writing-reviewing and editing, E.J.; project administration, V.M.G.-L. and J.J. All authors have read and agreed to the published version of the manuscript.

Funding: This research received no external funding.

Data Availability Statement: Not applicable. 
Acknowledgments: We thank Stephen Davids for proofreading this article.

Conflicts of Interest: The authors declare no conflict of interest.

\section{References}

1. Schalk, S.; Adam, V.; Arnold, E.; Brieden, K.; Voronov, A.; Witzke, H.D. UV-lamps for disinfection and advanced oxidation-lamp types, technologies and applications. IUVA 2006, 8, 32-37.

2. Gómez-López, V.M.; Ragaert, P.; Debevere, J.; Devlieghere, F. Decontamination Methods to Prolong the Shelf-life of Minimally Processed Vegetables, State-of-the-art. Crit. Rev. Food Sci. Nutr. 2008, 48, 487-495. [CrossRef]

3. McDonald, K.; Curry, R.; Clevenger, T.; Unklesbay, K.; Eisenstark, A.; Golden, J.; Morgan, R. A comparison of pulsed and continuous ultraviolet light sources for the decontamination of surfaces. IEEE Trans. Plasma Sci. 2000, 28, 1581-1587. [CrossRef]

4. Bohrerova, Z.; Shemer, H.; Lantis, R.; Impellitteri, C.A.; Linden, K.G. Comparative disinfection efficiency of pulsed and continuous-wave UV irradiation technologies. Water Res. 2008, 42, 2975-2982. [CrossRef]

5. Braslavsky, S.E. Glossary of terms used in photochemistry. Pure Appl. Chem. 1996, 68, 2223-2286. [CrossRef]

6. Gómez-López, V.M.; Bolton, J.R. An Approach to Standardize Methods for Fluence Determination in Bench-Scale Pulsed Light Experiments. Food Bioprocess Technol. 2016, 9, 1040-1048. [CrossRef]

7. Bolton, J.R. Ultraviolet Applications Handbook, 3rd ed.; ICC Lifelong Learn Inc.: Edmonton, AB, Canada, 2013.

8. Water-Technology. Catskill-Delaware UV Water Treatment Facility. Available online: https://www.water-technology.net/ projects / catskill-delaware-ultraviolet-water-treatment-facility/ (accessed on 4 October 2021).

9. Fan, X.; Huang, R.; Chen, H. Application of ultraviolet C technology for surface decontamination of fresh produce. Trends Food Sci. Technol. 2017, 70, 9-19. [CrossRef]

10. Delorme, M.M.; Guimarães, J.T.; Coutinho, N.M.; Balthazar, C.F.; Rocha, R.S.; Silva, R.; Margalho, L.P.; Pimentel, T.C.; Silva, M.C.; Freitas, M.Q.; et al. Ultraviolet radiation: An interesting technology to preserve quality and safety of milk and dairy foods. Trends Food Sci. Technol. 2020, 102, 146-154. [CrossRef]

11. World Health Organization. WHO Estimates of the Global Burden of Foodborne Diseases: Foodborne Disease Burden Epidemiology Reference Group 2007-2015. Available online: https://apps.who.int/iris/handle/10665/199350 (accessed on 1 November 2021).

12. Van Boxstael, S.; Habib, I.; Jacxsens, L.; De Vocht, M.; Baert, L.; Van De Perre, E.; Rajkovic, A.; Galvez, F.L.; Sampers, I.; Spanoghe, P.; et al. Food safety issues in fresh produce: Bacterial pathogens, viruses and pesticide residues indicated as major concerns by stakeholders in the fresh produce chain. Food Control. 2013, 32, 190-197. [CrossRef]

13. Canadian Food Inspection Agency. Food Recall Warnings and Allergy Alerts. Available online: https://inspection.canada.ca/ food-recall-warnings-and-allergy-alerts/eng/1351519587174/1351519588221 (accessed on 1 November 2021).

14. U.S. Food \& Drug Administration. Recalls, Market Withdrawals, \& Safety Alerts. Available online: https://www.fda.gov/safety/ recalls-market-withdrawals-safety-alerts (accessed on 1 November 2021).

15. U.S. Food \& Drug Administration. Archive for Recalls, Market Withdrawals \& Safety Alerts. Available online: https:// www.fda.gov/safety/recalls-market-withdrawals-safety-alerts/archive-recalls-market-withdrawals-safety-alerts (accessed on 1 November 2021).

16. World Health Organization \& Food and Agriculture Organization of the United Nations. Viruses in Food: Scientific Advice to Support Risk Management Activities: Meeting Report. Available online: https://apps.who.int/iris/handle/10665/44030 (accessed on 1 November 2021).

17. Scallan, E.; Hoekstra, R.M.; Angulo, F.J.; Tauxe, R.V.; Widdowson, M.-A.; Roy, S.L.; Jones, J.L.; Griffin, P.M. Foodborne Illness Acquired in the United States-Major Pathogens. Emerg. Infect. Dis. 2011, 17, 7-15. [CrossRef] [PubMed]

18. World Health Organization. The Burden of Foodborne Diseases in the WHO European Region. 2017. Available online: https:/ / www.euro.who.int/en/health-topics/disease-prevention/food-safety/publications/2017/the-burden-of-foodbornediseases-in-the-who-european-region-2017 (accessed on 1 November 2021).

19. Di Cola, G.; Fantilli, A.C.; Pisano, M.B.; Ré, V.E. Foodborne transmission of hepatitis A and hepatitis E viruses: A literature review. Int. J. Food Microbiol. 2021, 338, 108986. [CrossRef]

20. Kokkinos, P.; Kozyra, I.; Lazic, S.; Bouwknegt, M.; Rutjes, S.; Willems, K.A.; Moloney, R.; Husman, A.M.D.R.; Kaupke, A.; Legaki, E.; et al. Harmonised Investigation of the Occurrence of Human Enteric Viruses in the Leafy Green Vegetable Supply Chain in Three European Countries. Food Environ. Virol. 2012, 4, 179-191. [CrossRef]

21. Lopman, B.; Gastañaduy, P.; Park, G.W.; Hall, A.J.; Parashar, U.D.; Vinje, J. Environmental transmission of norovirus gastroenteritis. Curr. Opin. Virol. 2012, 2, 96-102. [CrossRef] [PubMed]

22. Verhaelen, K.; Bouwknegt, M.; Carratalà, A.; Lodder-Verschoor, F.; Diez-Valcarce, M.; Rodríguez-Lázaro, D.; Husman, A.M.D.R.; Rutjes, S.A. Virus transfer proportions between gloved fingertips, soft berries, and lettuce, and associated health risks. Int. J. Food Microbiol. 2013, 166, 419-425. [CrossRef]

23. Chatziprodromidou, I.P.; Bellou, M.; Vantarakis, G.; Vantarakis, A. Viral outbreaks linked to fresh produce consumption: A systematic review. J. Appl. Microbiol. 2018, 124, 932-942. [CrossRef] [PubMed]

24. Nasheri, N.; Vester, A.; Petronella, N. Foodborne viral outbreaks associated with frozen produce. Epidemiol. Infect. 2019,147, e291. [CrossRef] [PubMed] 
25. Bernard, H.; Faber, M.; Wilking, H.; Haller, S.; Höhle, M.; Schielke, A.; Ducomble, T.; Siffczyk, C.; Merbecks, S.S.; Fricke, G.; et al. Large multistate outbreak of norovirus gastroenteritis associated with frozen strawberries, Germany, 2012. Eurosurveillance 2014, 19, 20719. [CrossRef]

26. Scavia, G.; Alfonsi, V.; Taffon, S.; Escher, M.; Bruni, R.; De Medici, D.; Di Pasquale, S.; Guizzardi, S.; Cappelletti, B.; Iannazzo, S.; et al. A large prolonged outbreak of hepatitis A associated with consumption of frozen berries, Italy, 2013-14. J. Med. Microbiol. 2017, 66, 342-349. [CrossRef] [PubMed]

27. Severi, E.; Verhoef, L.; Thornton, L.; Guzman-Herrador, B.R.; Faber, M.; Sundqvist, L.; Rimhanen-Finne, R.; Roque-Afonso, A.M.; Ngui, S.L.; Allerberger, F.; et al. Large and prolonged food-borne multistate hepatitis A outbreak in Europe associated with consumption of frozen berries, 2013 to 2014. Eurosurveillance 2015, 20, 21192. [CrossRef]

28. Wheeler, C.; Vogt, T.M.; Armstrong, G.L.; Vaughan, G.; Weltman, A.; Nainan, O.V.; Dato, V.; Xia, G.; Waller, K.; Amon, J.; et al. An Outbreak of Hepatitis A Associated with Green Onions. New Engl. J. Med. 2005, 353, 890-897. [CrossRef]

29. Meghnath, K.; Team, O.; Hasselback, P.; McCormick, R.; Prystajecky, N.; Taylor, M.; McIntyre, L.; Man, S.; Whitfield, Y.; Warshawsky, B.; et al. Outbreaks of Norovirus and Acute Gastroenteritis Associated with British Columbia Oysters, $2016-2017$. Food Environ. Virol. 2019, 11, 138-148. [CrossRef] [PubMed]

30. Woods, J.W.; Calci, K.R.; Marchant-Tambone, J.G.; Burkhardt, W. Detection and molecular characterization of norovirus from oysters implicated in outbreaks in the US. Food Microbiol. 2016, 59, 76-84. [CrossRef]

31. Wall, R.; Dymond, N.; Bell, A.; Thornley, C.; Buik, H.; Cumming, D.; Petersen, N. Two New Zealand outbreaks of norovirus gastroenteritis linked to commercially farmed oysters. N. Z. Med. J. 2011, 124, 63-71. [PubMed]

32. Pontrelli, G.; Boccia, D.; DI Renzi, M.; Massari, M.; Giugliano, F.; Celentano, L.P.; Taffon, S.; Genovese, D.; DI Pasquale, S.; Scalise, F.; et al. Epidemiological and virological characterization of a large community-wide outbreak of hepatitis A in southern Italy. Epidemiol. Infect. 2008, 136, 1027-1034. [CrossRef] [PubMed]

33. Viray, M.A.; Hofmeister, M.G.; Johnston, D.I.; Krishnasamy, V.P.; Nichols, C.; Foster, M.A.; Balajadia, R.; Wise, M.E.; Manuzak, A.; Lin, Y.; et al. Public health investigation and response to a hepatitis A outbreak from imported scallops consumed raw-Hawaii, 2016. Epidemiol. Infect. 2018, 147, e28. [CrossRef] [PubMed]

34. Gurav, Y.K.; Babu, G.R.; Vinu, K.P.; Lole, K.S. Suspected spread of hepatitis A virus from a restaurant among adults in rural area of the Kerala state, India. Epidemiol. Infect. 2019, 147, e210. [CrossRef]

35. Li, P.; Liu, J.; Li, Y.; Su, J.; Ma, Z.; Bramer, W.M.; Cao, W.; De Man, R.A.; Peppelenbosch, M.P.; Pan, Q. The global epidemiology of hepatitis E virus infection: A systematic review and meta-analysis. Liver Int. Off. J. Int. Assoc. Study Liver 2020, 40, 1516-1528. [CrossRef] [PubMed]

36. EFSA Panel on Biological Hazards (BIOHAZ); Ricci, A.; Allende, A.; Bolton, D.; Chemaly, M.; Davies, R.; Fernandez Escamez, P.S.; Herman, L.; Koutsoumanis, K.; Lindqvist, R.; et al. Public health risks associated with hepatitis E virus (HEV) as a food-borne pathogen. EFSA J. 2017, 15, e04886. [CrossRef]

37. Crossan, C.; Baker, P.J.; Craft, J.; Takeuchi, Y.; Dalton, H.R.; Scobie, L. Hepatitis E Virus Genotype 3 in Shellfish, United Kingdom. Emerg. Infect. Dis. 2012, 18, 2085-2087. [CrossRef] [PubMed]

38. La Rosa, G.; Proroga, Y.T.R.; De Medici, D.; Capuano, F.; Iaconelli, M.; della Libera, S.; Suffredini, E. First Detection of Hepatitis E Virus in Shellfish and in Seawater from Production Areas in Southern Italy. Food Environ. Virol. 2018, 10, 127-131. [CrossRef] [PubMed]

39. Li, T.-C.; Miyamura, T.; Takeda, N. Detection of hepatitis E virus RNA from the bivalve Yamato-Shijimi (Corbicula japonica) in Japan. Am. J. Trop. Med. Hyg. 2007, 76, 170-172. [CrossRef]

40. Purpari, G.; Macaluso, G.; Di Bella, S.; Gucciardi, F.; Mira, F.; Di Marco, P.; Lastra, A.; Petersen, E.; La Rosa, G.; Guercio, A. Molecular characterization of human enteric viruses in food, water samples, and surface swabs in Sicily. Int. J. Infect. Dis. IJID Off. Publ. Int. Soc. Infect. Dis. 2019, 80, 66-72. [CrossRef] [PubMed]

41. Brassard, J.; Gagné, M.-J.; Généreux, M.; Côté, C. Detection of Human Food-Borne and Zoonotic Viruses on Irrigated, Field-Grown Strawberries. Appl. Environ. Microbiol. 2012, 78, 3763-3766. [CrossRef]

42. Maunula, L.; Kaupke, A.; Vasickova, P.; Söderberg, K.; Kozyra, I.; Lazic, S.; van der Poel, W.H.; Bouwknegt, M.; Rutjes, S.; Willems, K.A.; et al. Tracing enteric viruses in the European berry fruit supply chain. Int. J. Food Microbiol. 2013, 167, 177-185. [CrossRef] [PubMed]

43. Demirci, M.; Yiğin, A.; Ünlü, O.; Altun, S.K. Farklı Hayvanlardan Elde Edilen Çiğ Sütlerde HEV RNA Miktarının ve Genotiplerinin Tespiti. Mikrobiyoloji Bulteni 2019, 53, 43-52. [CrossRef] [PubMed]

44. Dziedzinska, R.; Krzyzankova, M.; Bena, M.; Vasickova, P. Evidence of Hepatitis E Virus in Goat and Sheep Milk. Viruses 2020, 12, 1429. [CrossRef] [PubMed]

45. Montone, A.M.I.; De Sabato, L.; Suffredini, E.; Alise, M.; Zaccherini, A.; Volzone, P.; Di Maro, O.; Neola, B.; Capuano, F.; Di Bartolo, I. Occurrence of HEV-RNA in Italian Regional Pork and Wild Boar Food Products. Food Environ. Virol. 2019, 11, 420-426. [CrossRef] [PubMed]

46. Pereira, J.G.; Soares, V.M.; Gil De Souza, F.; Tadielo, L.E.; dos Santos, E.A.R.; Brum, M.C.S.; Henzel, A.; Duval, E.H.; Spilki, F.R.; Da Silva, W.P. Hepatitis A Virus, Hepatitis E Virus, and Rotavirus in Foods of Animal Origin Traded at the Borders of Brazil, Argentina, and Uruguay. Food Environ. Virol. 2018, 10, 365-372. [CrossRef] 
47. Malek, M.; Barzilay, E.; Kramer, A.; Camp, B.; Jaykus, L.; Escudero-Abarca, B.; Derrick, G.; White, P.; Gerba, C.; Higgins, C.; et al. Outbreak of Norovirus Infection among River Rafters Associated with Packaged Delicatessen Meat, Grand Canyon, 2005. Clin. Infect. Dis. Off. Publ. Infect. Dis. Soc. Am. 2009, 48, 31-37. [CrossRef]

48. Prasad, B.V.V.; Schmid, M.F. Principles of Virus Structural Organization. Adv. Exp. Med. Biol. 2012, 726, 17-47. [CrossRef] [PubMed]

49. Viruses, I.C.o.T.o. Introduction to Virus Taxonomy. Available online: https://talk.ictvonline.org/taxonomy/w/ictv-taxonomy (accessed on 14 September 2021).

50. Mateu, M.G. Introduction: The Structural Basis of Virus Function. Subcell Biochem. 2013, 68, 3-51. [CrossRef] [PubMed]

51. Shang, J.; Wan, Y.; Liu, C.; Yount, B.; Gully, K.; Yang, Y.; Auerbach, A.; Peng, G.; Baric, R.; Li, F. Structure of mouse coronavirus spike protein complexed with receptor reveals mechanism for viral entry. PLoS Pathog. 2020, 16, e1008392. [CrossRef] [PubMed]

52. Haralampiev, I.; Prisner, S.; Nitzan, M.; Schade, M.; Jolmes, F.; Schreiber, M.; Loidolt-Krüger, M.; Jongen, K.; Chamiolo, J.; Nilson, N.; et al. Selective flexible packaging pathways of the segmented genome of influenza A virus. Nat. Commun. 2020, 11, 4355. [CrossRef] [PubMed]

53. Cui, J.; Schlub, T.; Holmes, E.C. An Allometric Relationship between the Genome Length and Virion Volume of Viruses. J. Virol. 2014, 88, 6403-6410. [CrossRef] [PubMed]

54. Edwards, K.F.; Steward, G.F.; Schvarcz, C.R. Making sense of virus size and the tradeoffs shaping viral fitness. Ecol. Lett. 2021, 24, 363-373. [CrossRef] [PubMed]

55. Louten, J. Chapter 2-Virus Structure and Classification. In Essential Human Virology; Elsevier: Amsterdam, The Netherlands, 2016; pp. 19-29. [CrossRef]

56. Fermin, G. Host Range, Host-Virus Interactions, and Virus Transmission. Viruses 2018, 2018, 101-134. [CrossRef]

57. Fischer, M.G. The Virophage Family Lavidaviridae. Curr. Issues Mol. Biol. 2021, 40, 1-24. [CrossRef]

58. Jolly, C.; Sattentau, Q.J. Attachment Factors. Adv. Exp. Med. Biol. 2006, 790, 1-23. [CrossRef]

59. Karst, S.M. Pathogenesis of Noroviruses, Emerging RNA Viruses. Viruses 2010, 2, 748-781. [CrossRef]

60. Ryu, W. Virus Life Cycle. Mol. Virol. Hum. Pathog. Viruses 2017, 2017, 31-45. [CrossRef]

61. Payet, J.P.; Suttle, C.A. To kill or not to kill: The balance between lytic and lysogenic viral infection is driven by trophic status. Limnol. Oceanogr. 2013, 58, 465-474. [CrossRef]

62. Hirneisen, K.A.; Black, E.P.; Cascarino, J.L.; Fino, V.R.; Hoover, D.G.; Kniel, K.E. Viral Inactivation in Foods: A Review of Traditional and Novel Food-Processing Technologies. Compr. Rev. Food Sci. Food Saf. 2010, 9, 3-20. [CrossRef] [PubMed]

63. Conley, L.; Tao, Y.; Henry, A.; Koepf, E.; Cecchini, D.; Pieracci, J.; Ghose, S. Evaluation of eco-friendly zwitterionic detergents for enveloped virus inactivation. Biotechnol. Bioeng. 2017, 114, 813-820. [CrossRef] [PubMed]

64. Guo, A.; Shieh, Y.C.; Wang, R.R. Features of material surfaces affecting virus adhesion as determined by nanoscopic quantification. Colloids Surf. A Physicochem. Eng. Asp. 2020, 602, 125109. [CrossRef]

65. Atmar, R.L.; Ramani, S.; Estes, M.K. Human noroviruses: Recent advances in a 50-year history. Curr. Opin. Infect. Dis. 2018, 31, 422-432. [CrossRef] [PubMed]

66. Chhabra, P.; De Graaf, M.; Parra, G.I.; Chan, M.C.-W.; Green, K.; Martella, V.; Wang, Q.; White, P.A.; Katayama, K.; Vennema, H.; et al. Updated classification of norovirus genogroups and genotypes. J. Gen. Virol. 2019, 100, 1393-1406. [CrossRef] [PubMed]

67. Ozaki, K.; Matsushima, Y.; Nagasawa, K.; Aso, J.; Saraya, T.; Yoshihara, K.; Murakami, K.; Motoya, T.; Ryo, A.; Kuroda, M.; et al. Molecular Evolution of the Protease Region in Norovirus Genogroup II. Front. Microbiol. 2019, 10, 2991. [CrossRef] [PubMed]

68. Chhabra, P.; De Graaf, M.; Parra, G.I.; Chan, M.C.-W.; Green, K.; Martella, V.; Wang, Q.; White, P.A.; Katayama, K.; Vennema, H.; et al. Corrigendum: Updated classification of norovirus genogroups and genotypes. J. Gen. Virol. 2020, 101, 893. [CrossRef]

69. Ramani, S.; Atmar, R.L.; Estes, M.K. Epidemiology of human noroviruses and updates on vaccine development. Curr. Opin. Gastroenterol. 2014, 30, 25-33. [CrossRef] [PubMed]

70. Xue, L.; Wu, Q.; Cai, W.; Zhang, J.; Guo, W. Molecular characterization of new emerging GII.17 norovirus strains from South China. Infect. Genet. Evol. 2016, 40, 1-7. [CrossRef]

71. Zhou, H.-L.; Zhen, S.-S.; Wang, J.-X.; Zhang, C.-J.; Qiu, C.; Wang, S.-M.; Jiang, X.; Wang, X.-Y. Burden of acute gastroenteritis caused by norovirus in China: A systematic review. J. Infect. 2017, 75, 216-224. [CrossRef]

72. Malm, M.; Tamminen, K.; Lappalainen, S.; Uusi-Kerttula, H.; Vesikari, T.; Blazevic, V. Genotype Considerations for Virus-like Particle-Based Bivalent Norovirus Vaccine Composition. Clin. Vaccine Immunol. 2015, 22, 656-663. [CrossRef] [PubMed]

73. Bernstein, D.I.; Atmar, R.L.; Lyon, G.M.; Treanor, J.J.; Chen, W.H.; Jiang, X.; Vinje, J.; Gregoricus, N.; Frenck, R.W., Jr.; Moe, C.L.; et al. Norovirus Vaccine against Experimental Human GII.4 Virus Illness: A Challenge Study in Healthy Adults. J. Infect. Dis. 2015, 211, 870-878. [CrossRef] [PubMed]

74. Treanor, J.; Sherwood, J.; Cramer, J.P.; Le Cam Bouveret, N.; Lin, S.; Baehner, F.; Borkowski, A.; The NOR-204 Investigators. A phase 2 study of the bivalent VLP norovirus vaccine candidate in older adults; impact of MPL adjuvant or a second dose. Vaccine 2020, 38, 5842-5850. [CrossRef] [PubMed]

75. Tamminen, K.; Lappalainen, S.; Huhti, L.; Vesikari, T.; Blazevic, V. Trivalent Combination Vaccine Induces Broad Heterologous Immune Responses to Norovirus and Rotavirus in Mice. PLoS ONE 2013, 8, e70409. [CrossRef] [PubMed] 
76. Cuevas, J.; Combe, M.; Torres-Puente, M.; Garijo, R.; Guix, S.; Buesa, J.; Rodriguez-Diaz, J.; Sanjuán, R. Human norovirus hyper-mutation revealed by ultra-deep sequencing. Infect. Genet. Evol. 2016, 41, 233-239. [CrossRef]

77. Sala, M.R.; Arias, C.; Domínguez, A.; Bartolomé, R.; Muntada, J.M. Foodborne outbreak of gastroenteritis due to Norovirus and Vibrio parahaemolyticus. Epidemiol. Infect. 2009, 137, 626-629. [CrossRef]

78. Zuckerman, A. Chapter 70, 4th ed.; University of Texas Medical Branch at Galveston: Galveston, TX, USA, 1996.

79. Brown, E.A.; Day, S.P.; Jansen, R.W.; Lemon, S.M. The 5' nontranslated region of hepatitis A virus RNA: Secondary structure and elements required for translation in vitro. J. Virol. 1991, 65, 5828-5838. [CrossRef]

80. Paul, A.V.; Tada, H.; von der Helm, K.; Wissel, T.; Kiehn, R.; Wimmer, E.; Deinhardt, F. The entire nucleotide sequence of the genome of human hepatitis A virus (isolate MBB). Virus Res. 1987, 8, 153-171. [CrossRef]

81. Konduru, K.; Nakamura, S.M.; Kaplan, G.G. Hepatitis A virus (HAV) packaging size limit. Virol. J. 2009, 6, 204. [CrossRef] [PubMed]

82. Desbois, D.; Couturier, E.; Mackiewicz, V.; Graube, A.; Letort, M.-J.; Dussaix, E.; Roque-Afonso, A.-M. Epidemiology and Genetic Characterization of Hepatitis A Virus Genotype IIA. J. Clin. Microbiol. 2010, 48, 3306-3315. [CrossRef] [PubMed]

83. Lemon, S.M.; Jansen, R.W.; Brown, E.A. Genetic, antigenic and biological differences between strains of hepatitis A virus. Vaccine 1992, 10 (Suppl. 1), S40-S44. [CrossRef]

84. Sagliocca, L.; Amoroso, P.; Stroffolini, T.; Adamo, B.; Tosti, M.E.; Lettieri, G.; Esposito, C.; Buonocore, S.; Pierri, P.; Mele, A. Efficacy of hepatitis A vaccine in prevention of secondary hepatitis A infection: A randomised trial. Lancet 1999, 353, 1136-1139. [CrossRef]

85. Keeffe, E.B.; Iwarson, S.; McMahon, B.J.; Lindsay, K.L.; Koff, R.S.; Manns, M.; Baumgarten, R.; Wiese, M.; Fourneau, M.; Safary, A.; et al. Safety and immunogenicity of hepatitis A vaccine in patients with chronic liver disease. Hepatology 1998, 27, 881-886. [CrossRef] [PubMed]

86. Van Damme, P.; Thoelen, S.; Cramm, M.; de Groote, K.; Safary, A.; Meheus, A. Inactivated hepatitis A vaccine: Reactogenicity, immunogenicity, and long-term antibody persistence. J. Med Virol. 1994, 44, 446-451. [CrossRef] [PubMed]

87. Singh, M.P.; Majumdar, M.; Thapa, B.R.; Gupta, P.K.; Khurana, J.; Budhathoki, B.; Ratho, R.K. Molecular characterization of hepatitis A virus strains in a tertiary care health set up in north western India. Indian J. Med. Res. 2015, 141, 213-220. [CrossRef]

88. Franco, E.; Meleleo, C.; Serino, L.; Sorbara, D.; Zaratti, L. Hepatitis A: Epidemiology and prevention in developing countries. World J. Hepatol. 2012, 4, 68-73. [CrossRef] [PubMed]

89. Hu, X.; Collier, M.G.; Xu, F. Hepatitis A Outbreaks in Developed Countries: Detection, Control, and Prevention. Foodborne Pathog. Dis. 2020, 17, 166-171. [CrossRef]

90. Gould, L.H.; Kline, J.; Monahan, C.; Vierk, K. Outbreaks of Disease Associated with Food Imported into the United States, 1996-2014(1). Emerg. Infect. Dis. 2017, 23, 525-528. [CrossRef]

91. Webb, G.W.; Dalton, H.R. Hepatitis E: An underestimated emerging threat. Ther. Adv. Infect. Dis. 2019, 6, 2049936119837162. [CrossRef] [PubMed]

92. Harrison, L.; DiCaprio, E. Hepatitis E Virus: An Emerging Foodborne Pathogen. Front. Sustain. Food Syst. 2018, 2, 14. [CrossRef]

93. Yugo, D.M.; Meng, X.-J. Hepatitis E Virus: Foodborne, Waterborne and Zoonotic Transmission. Int. J. Environ. Res. Public Health 2013, 10, 4507-4533. [CrossRef] [PubMed]

94. Pavio, N.; Merbah, T.; Thébault, A. Frequent Hepatitis E Virus Contamination in Food Containing Raw Pork Liver, France. Emerg. Infect. Dis. 2014, 20, 1925-1927. [CrossRef] [PubMed]

95. Horvatits, T.; Ozga, A.-K.; Westhoelter, D.; Hartl, J.; Manthey, C.F.; Lütgehetmann, M.; Rauch, G.; Kriston, L.; Lohse, A.W.; Bendall, R.; et al. Hepatitis E seroprevalence in the Americas: A systematic review and meta-analysis. Liver Int. Off. J. Int. Assoc. Study Liver 2018, 38, 1951-1964. [CrossRef] [PubMed]

96. Richards, G.P. Critical Review of Norovirus Surrogates in Food Safety Research: Rationale for Considering Volunteer Studies. Food Environ. Virol. 2012, 4, 6-13. [CrossRef] [PubMed]

97. Hewitt, J.; Rivera-Aban, M.; Greening, G. Evaluation of murine norovirus as a surrogate for human norovirus and hepatitis A virus in heat inactivation studies. J. Appl. Microbiol. 2009, 107, 65-71. [CrossRef]

98. Rzeżutka, A.; Cook, N. Survival of human enteric viruses in the environment and food. FEMS Microbiol. Rev. 2004, 28, 441-453. [CrossRef] [PubMed]

99. Knight, A.; Haines, J.; Stals, A.; Li, D.; Uyttendaele, M.; Knight, A.; Jaykus, L.-A. A systematic review of human norovirus survival reveals a greater persistence of human norovirus RT-qPCR signals compared to those of cultivable surrogate viruses. Int. J. Food Microbiol. 2016, 216, 40-49. [CrossRef]

100. Yeargin, T.; Buckley, D.; Fraser, A.; Jiang, X. The survival and inactivation of enteric viruses on soft surfaces: A systematic review of the literature. Am. J. Infect. Control. 2016, 44, 1365-1373. [CrossRef]

101. Farkas, T.; Cross, R.W.; Hargitt, E.; Lerche, N.W.; Morrow, A.L.; Sestak, K. Genetic Diversity and Histo-Blood Group Antigen Interactions of Rhesus Enteric Caliciviruses. J. Virol. 2010, 84, 8617-8625. [CrossRef]

102. Tian, P.; Yang, D.; Quigley, C.; Chou, M.; Jiang, X. Inactivation of the Tulane Virus, a Novel Surrogate for the Human Norovirus. J. Food Prot. 2013, 76, 712-718. [CrossRef]

103. Tan, M.; Wei, C.; Huang, P.; Fan, Q.; Quigley, C.; Xia, M.; Fang, H.; Zhang, X.; Zhong, W.; Klassen, J.S.; et al. Tulane virus recognizes sialic acids as cellular receptors. Sci. Rep. 2015, 5, 11784. [CrossRef] [PubMed] 
104. O'Shea, H.; Blacklaws, B.A.; Collins, P.J.; McKillen, J.; Fitzgerald, R. Viruses Associated With Foodborne Infections. Ref. Modul. Life Sci. 2019. [CrossRef]

105. Sair, A.I.; D’Souza, D.H.; Jaykus, L.A. Human Enteric Viruses as Causes of Foodborne Disease. Compr. Rev. Food Sci. Food Saf. 2002, 1, 73-89. [CrossRef]

106. Rivadulla, E.; Romalde, J.L. A Comprehensive Review on Human Aichi Virus. Virol. Sin. 2020, 35, 501-516. [CrossRef]

107. Cromeans, T.; Park, G.W.; Costantini, V.; Lee, D.; Wang, Q.; Farkas, T.; Lee, A.; Vinjé, J. Comprehensive Comparison of Cultivable Norovirus Surrogates in Response to Different Inactivation and Disinfection Treatments. Appl. Environ. Microbiol. 2014, 80, 5743-5751. [CrossRef] [PubMed]

108. Bardell, D. Survival of Herpes Simplex Virus Type 1 on Some Common Foods Routinely Touched before Consumption. J. Food Prot. 1997, 60, 1259-1261. [CrossRef] [PubMed]

109. Ward, H.M.V. Experiments on the action of light on Bacillus anthracis. Proc. R. Soc. Lond. 1893, 52, 393-400. [CrossRef]

110. Meechan, P.J.; Wilson, C. Use of Ultraviolet Lights in Biological Safety Cabinets: A Contrarian View. Appl. Biosaf. $2006,11,222-227$. [CrossRef]

111. Kowalski, W. Ultraviolet Germicidal Irradiation Handbook, 1st ed.; Springer: Berlin/Heidelberg, Germany, 2009. [CrossRef]

112. Berg, M.; Bergman, B.; Hoborn, J. Ultraviolet radiation compared to an ultra-clean air enclosure. Comparison of air bacteria counts in operating rooms. J. Bone Jt. Surgery 1991, 73, 811-815. [CrossRef] [PubMed]

113. Reed, N.G. The History of Ultraviolet Germicidal Irradiation for Air Disinfection. Public Health Rep. 2010, 125, 15-27. [CrossRef] [PubMed]

114. Selma, M.V.; Allende, A.; Lopez-Galvez, F.; Conesa, M.A.; Gil, M.I. Disinfection potential of ozone, ultraviolet-C and their combination in wash water for the fresh-cut vegetable industry. Food Microbiol. 2008, 25, 809-814. [CrossRef]

115. Bintsis, T.; Litopoulou-Tzanetaki, E.; Robinson, R.K. Existing and potential applications of ultraviolet light in the food industry-A critical review. J. Sci. Food Agric. 2000, 80, 637-645. [CrossRef]

116. Lytle, C.D.; Sagripanti, J.-L. Predicted Inactivation of Viruses of Relevance to Biodefense by Solar Radiation. J. Virol. 2005, 79, 14244-14252. [CrossRef] [PubMed]

117. Roberts, P.; Hope, A. Virus inactivation by high intensity broad spectrum pulsed light. J. Virol. Methods 2003, 110, 61-65. [CrossRef]

118. Buonanno, M.; Welch, D.; Shuryak, I.; Brenner, D.J. Far-UVC light (222 nm) efficiently and safely inactivates airborne human coronaviruses. Sci. Rep. 2020, 10, 10285. [CrossRef]

119. Butot, S.; Cantergiani, F.; Moser, M.; Jean, J.; Lima, A.; Michot, L.; Putallaz, T.; Stroheker, T.; Zuber, S. UV-C inactivation of foodborne bacterial and viral pathogens and surrogates on fresh and frozen berries. Int. J. Food Microbiol. 2018, $275,8-16$. [CrossRef]

120. Linden, K.G.; Thurston, J.; Schaefer, R.; Malley, J.P. Enhanced UV Inactivation of Adenoviruses under Polychromatic UV Lamps. Appl. Environ. Microbiol. 2007, 73, 7571-7574. [CrossRef] [PubMed]

121. Huffman, D.E.; Gennaccaro, A.; Rose, J.B.; Dussert, B.W. Low- and medium-pressure UV inactivation of microsporidia Encephalitozoon intestinalis. Water Res. 2002, 36, 3161-3164. [CrossRef]

122. Sholtes, K.; Linden, K.G. Pulsed and continuous light UV LED: Microbial inactivation, electrical, and time efficiency. Water Res. 2019, 165, 114965. [CrossRef] [PubMed]

123. Mackenzie, D. Ultraviolet Light Fights New Virus. Engineering 2020, 6, 851-853. [CrossRef]

124. Sanchez, A.G.; Smart, W.D. Surface Disinfection using Ultraviolet Lightwith a Mobile Manipulation Robot. arXiv 2021, arXiv:2104.10739.

125. Cutler, T.D.; Zimmerman, J.J. Ultraviolet irradiation and the mechanisms underlying its inactivation of infectious agents. Anim. Health Res. Rev. Conf. Res. Work. Anim. Dis. 2011, 12, 15-23. [CrossRef] [PubMed]

126. Pereira, R.; Bicalho, M.; Machado, V.; Lima, S.; Teixeira, A.; Warnick, L.; Bicalho, R. Evaluation of the effects of ultraviolet light on bacterial contaminants inoculated into whole milk and colostrum, and on colostrum immunoglobulin G. J. Dairy Sci. 2014, 97, 2866-2875. [CrossRef] [PubMed]

127. Rauth, A.M. The Physical State of Viral Nucleic Acid and the Sensitivity of Viruses to Ultraviolet Light. Biophys. J. 1965, 5, 257-273. [CrossRef]

128. Friedberg, E.C.; Walker, G.C.; Siede, W.; Wood, R.D. DNA Repair and Mutagenesis; American Society for Microbiology Press: Washington, DC, USA, 1995; p. 698.

129. Murphy, T.M.; Gordon, M.P. Photobiology of RNA Viruses; Springer: Boston, MA, USA, 1981; pp. 285-351. [CrossRef]

130. Tseng, C.-C.; Li, C.-S. Inactivation of Viruses on Surfaces by Ultraviolet Germicidal Irradiation. J. Occup. Environ. Hyg. 2007, 4, 400-405. [CrossRef] [PubMed]

131. Miller, R.L.; Plagemann, P.G.W. Effect of Ultraviolet Light on Mengovirus: Formation of Uracil Dimers, Instability and Degradation of Capsid, and Covalent Linkage of Protein to Viral RNA. J. Virol. 1974, 13, 729-739. [CrossRef]

132. Brickner, P.W.; Vincent, R.L.; First, M.; Nardell, E.; Murray, M.; Kaufman, W. The application of ultraviolet germicidal irradiation to control transmission of airborne disease: Bioterrorism countermeasure. Public Health Rep. 2003, 118, 99-114. [CrossRef]

133. Beck, S.E.; Rodriguez, R.A.; Hawkins, M.A.; Hargy, T.M.; Larason, T.C.; Linden, K.G. Comparison of UV-Induced Inactivation and RNA Damage in MS2 Phage across the Germicidal UV Spectrum. Appl. Environ. Microbiol. 2015, 82, 1468-1474. [CrossRef]

134. Buonanno, M.; Ponnaiya, B.; Welch, D.; Stanislauskas, M.; Randers-Pehrson, G.; Smilenov, L.; Lowy, F.D.; Owens, D.M.; Brenner, D.J. Germicidal Efficacy and Mammalian Skin Safety of 222-nm UV Light. Radiat. Res. 2017, 187, 483-491. [CrossRef] 
135. Lo, C.-W.; Matsuura, R.; Iimura, K.; Wada, S.; Shinjo, A.; Benno, Y.; Nakagawa, M.; Takei, M.; Aida, Y. UVC disinfects SARS-CoV-2 by induction of viral genome damage without apparent effects on viral morphology and proteins. Sci. Rep. 2021, 11, 13804. [CrossRef]

136. Rezaie, A.; Leite, G.G.S.; Melmed, G.Y.; Mathur, R.; Villanueva-Millan, M.J.; Parodi, G.; Sin, J.; Germano, J.F.; Morales, W.; Weitsman, S.; et al. Ultraviolet A light effectively reduces bacteria and viruses including coronavirus. PLoS ONE 2020, 15, e0236199. [CrossRef] [PubMed]

137. Eischeid, A.C.; Linden, K.G. Molecular Indications of Protein Damage in Adenoviruses after UV Disinfection. Appl. Environ. Microbiol. 2011, 77, 1145-1147. [CrossRef] [PubMed]

138. Nuanualsuwan, S.; Cliver, D.O. Capsid Functions of Inactivated Human Picornaviruses and Feline Calicivirus. Appl. Environ. Microbiol. 2003, 69, 350-357. [CrossRef] [PubMed]

139. Beck, S.E.; Hull, N.M.; Poepping, C.; Linden, K.G. Wavelength-Dependent Damage to Adenoviral Proteins across the Germicidal UV Spectrum. Environ. Sci. Technol. 2018, 52, 223-229. [CrossRef] [PubMed]

140. Vimont, A.; Fliss, I.; Jean, J.; Deng, Y.; Liu, X.; Wu, J.; Lee, J.; Chen, S.; Cheng, Y.; Zhang, C.; et al. Efficacy and Mechanisms of Murine Norovirus Inhibition by Pulsed-Light Technology. Appl. Environ. Microbiol. 2015, 81, 2950-2957. [CrossRef]

141. Sancar, A. No "End of History" for Photolyases. Science 1996, 272, 48-49. [CrossRef] [PubMed]

142. Srinivasan, V.; Schnitzlein, W.M.; Tripathy, D.N. Fowlpox Virus Encodes a Novel DNA Repair Enzyme, CPD-Photolyase, That Restores Infectivity of UV Light-Damaged Virus. J. Virol. 2001, 75, 1681-1688. [CrossRef]

143. Jean, J.; Morales-Rayas, R.; Anoman, M.-N.; Lamhoujeb, S. Inactivation of hepatitis A virus and norovirus surrogate in suspension and on food-contact surfaces using pulsed UV light (pulsed light inactivation of food-borne viruses). Food Microbiol. 2011, 28, 568-572. [CrossRef]

144. Hijnen, W.A.M.; Beerendonk, E.F.; Medema, G.J. Inactivation credit of UV radiation for viruses, bacteria and protozoan (oo)cysts in water: A review. Water Res. 2006, 40, 3-22. [CrossRef]

145. Lamont, Y.; Rzeżutka, A.; Anderson, J.; MacGregor, S.; Given, M.; Deppe, C.; Cook, N. Pulsed UV-light inactivation of poliovirus and adenovirus. Lett. Appl. Microbiol. 2007, 45, 564-567. [CrossRef]

146. Huang, Y.; Ye, M.; Cao, X.; Chen, H. Pulsed light inactivation of murine norovirus, Tulane virus, Escherichia coli O157:H7 and Salmonella in suspension and on berry surfaces. Food Microbiol. 2017, 61, 1-4. [CrossRef]

147. Belliot, G.; Loutreul, J.; Estienney, M.; Cazeaux, C.; Nicorescu, I.; Aho, S.; Gervais, P.; Orange, N.; Pothier, P.; Morin, T. Potential of Pulsed Light to Inactivate Bacteriophage MS2 in Simple Liquid Medium and on Complex Foodstuffs. Food Environ. Virol. 2013, 5, 176-179. [CrossRef]

148. Emmoth, E.; Rovira, J.; Rajkovic, A.; Corcuera, E.; Pérez, D.W.; Dergel, I.; Ottoson, J.R.; Widén, F. Inactivation of Viruses and Bacteriophages as Models for Swine Hepatitis E Virus in Food Matrices. Food Environ. Virol. 2017, 9, 20-34. [CrossRef]

149. Huang, Y.; Chen, H. Inactivation of Escherichia coli O157:H7, Salmonella and human norovirus surrogate on artificially contaminated strawberries and raspberries by water-assisted pulsed light treatment. Food Res. Int. 2015, 72, 1-7. [CrossRef]

150. Bhullar, M.; Patras, A.; Kilonzo-Nthenge, A.; Pokharel, B.; Sasges, M. Ultraviolet inactivation of bacteria and model viruses in coconut water using a collimated beam system. Food Sci. Technol. Int. 2019, 25, 562-572. [CrossRef] [PubMed]

151. Bhullar, M.; Patras, A.; Kilanzo-Nthenge, A.; Pokharel, B.; Yannam, S.K.; Rakariyatham, K.; Pan, C.; Xiao, H.; Sasges, M. Microbial inactivation and cytotoxicity evaluation of UV irradiated coconut water in a novel continuous flow spiral reactor. Food Res. Int. 2018, 103, 59-67. [CrossRef] [PubMed]

152. Gunter-Ward, D.M.; Patras, A.; Bhullar, M.; Kilonzo-Nthenge, A.; Pokharel, B.; Sasges, M. Efficacy of ultraviolet (UV-C) light in reducing foodborne pathogens and model viruses in skim milk. J. Food Process Preserv. 2018, 42, e13485. [CrossRef]

153. Ward, D.M.; Patras, A.; Kilonzo-Nthenge, A.; Yannam, S.K.; Pan, C.; Xiao, H.; Sasges, M. UV-C treatment on the safety of skim milk: Effect on microbial inactivation and cytotoxicity evaluation. J. Food Process Eng. 2019, 42, e12944. [CrossRef]

154. Gómez-López, V.M.; Ragaert, P.; Debevere, J.; Devlieghere, F. Pulsed light for food decontamination: A review. Trends Food Sci. Technol. 2007, 18, 464-473. [CrossRef]

155. Park, S.Y.; Ha, S.-D. Ultraviolet-C Radiation on the Fresh Chicken Breast: Inactivation of Major Foodborne Viruses and Changes in Physicochemical and Sensory Qualities of Product. Food Bioprocess Technol. 2015, 8, 895-906. [CrossRef]

156. Hirneisen, K.A.; Kniel, K.E. Inactivation of internalized and surface contaminated enteric viruses in green onions. Int. J. Food Microbiol. 2013, 166, 201-206. [CrossRef]

157. Fino, V.R.; Kniel, K.E. UV Light Inactivation of Hepatitis A Virus, Aichi Virus, and Feline Calicivirus on Strawberries, Green Onions, and Lettuce. J. Food Prot. 2008, 71, 908-913. [CrossRef] [PubMed]

158. Ortiz-Solà, J.; Viñas, I.; Aguiló-Aguayo, I.; Bobo, G.; Abadias, M. An innovative water-assisted UV-C disinfection system to improve the safety of strawberries frozen under cryogenic conditions. Innov. Food Sci. Emerg. Technol. 2021, 73, 102756. [CrossRef]

159. Park, S.Y.; Kim, A.-N.; Lee, K.-H.; Ha, S.-D. Ultraviolet-C efficacy against a norovirus surrogate and hepatitis A virus on a stainless steel surface. Int. J. Food Microbiol. 2015, 211, 73-78. [CrossRef]

160. Liu, C.; Li, X.; Chen, H. Application of water-assisted ultraviolet light processing on the inactivation of murine norovirus on blueberries. Int. J. Food Microbiol. 2015, 214, 18-23. [CrossRef] [PubMed]

161. Moon, Y.; Han, S.; Son, J.W.; Park, S.H.; Ha, S.-D. Impact of ultraviolet-C and peroxyacetic acid against murine norovirus on stainless steel and lettuce. Food Control. 2021, 130, 108378. [CrossRef] 
162. Xie, Y.; Hajdok, C.; Mittal, G.S.; Warriner, K. Inactivation of MS2 F(+) Coliphage on Lettuce by a Combination of UV Light and Hydrogen Peroxide. J. Food Prot. 2008, 71, 903-907. [CrossRef] [PubMed]

163. Nasheri, N.; Harlow, J.; Chen, A.; Corneau, N.; Bidawid, S. Survival and Inactivation by Advanced Oxidative Process of Foodborne Viruses in Model Low-Moisture Foods. Food Environ. Virol. 2021, 13, 107-116. [CrossRef] [PubMed]

164. Gwynne, P.J.; Gallagher, M.P. Light as a Broad-Spectrum Antimicrobial. Front. Microbiol. 2018, 9, 119. [CrossRef]

165. Zoschke, K.; Börnick, H.; Worch, E. Vacuum-UV radiation at $185 \mathrm{~nm}$ in water treatment-A review. Water Res. 2014, 52, 131-145. [CrossRef] [PubMed]

166. Jubinville, E.; Girard, M.; Trudel-Ferland, M.; Fliss, I.; Jean, J. Inactivation of Murine Norovirus Suspended in Organic Matter Simulating Actual Conditions of Viral Contamination. Food Environ. Virol. 2021, 13, 544-552. [CrossRef]

167. Berry, N.L.; Overholt, E.P.; Fisher, T.J.; Williamson, C.E. Dissolved organic matter protects mosquito larvae from damaging solar UV radiation. PLoS ONE 2020, 15, e0240261. [CrossRef]

168. McClain, M.E.; Spendlove, R.S. Multiplicity Reactivation of Reovirus Particles after Exposure to Ultraviolet Light. J. Bacteriol. 1966, 92, 1422-1429. [CrossRef] [PubMed]

169. Thurston-Enriquez, J.A.; Haas, C.; Jacangelo, J.; Riley, K.; Gerba, C.P. Inactivation of Feline Calicivirus and Adenovirus Type 40 by UV Radiation. Appl. Environ. Microbiol. 2003, 69, 577-582. [CrossRef] [PubMed]

170. Pexara, A.; Govaris, A. Foodborne Viruses and Innovative Non-Thermal Food-Processing Technologies. Foods 2020, 9, 1520. [CrossRef] [PubMed]

171. Kulka, M.; Goswami, B. Pathogenic mechanisms of foodborne viral disease. Food Consum. Dis. Risk 2006, 2006, 343. [CrossRef]

172. U.S. Food \& Drug Administration. Code of Federal Regulations. Title 21, Volume 3, 21CFR179.39. Available online: https:/ / www.accessdata.fda.gov/scripts/cdrh/cfdocs/cfcfr/cfrsearch.cfm?fr=179.39 (accessed on 1 November 2021).

173. Koutchma, T. Status of International Regulations for Ultraviolet Treatment of Foods. IUVA News 2018, Quarter 2, 14-16. Available online: https://uvsolutionsmag.com/stories/pdf/IUVA_2018_Quarter2_full_Koutchma_links.pdf (accessed on 1 November 2021).

174. U.S. Food \& Drug Administration. Code of Federal Regulations. Title 21, Volume 3, 21CFR179.41. Available online: https://www.accessdata.fda.gov/scripts/cdrh/cfdocs/cfcfr/CFRSearch.cfm?fr=179.41 (accessed on 1 November 2021).

175. U.S. Food \& Drug Administration. Code of Federal Regulations. Title 21, Volume 3, 21CFR172.381. Available online: https:/ / www.accessdata.fda.gov/scripts/cdrh/cfdocs/cfcfr/CFRSearch.cfm?fr=172.381 (accessed on 1 November 2021).

176. European Food Safety Authority (EFSA). Commission Implementing Regulation (EU) 2017/2470 of 20 December 2017 Establishing the Union List of Novel Foods in Accordance with Regulation (EU) 2015/2283 of the European Parliament and of the Council on Novel Foods. Available online: https:/ / eur-lex.europa.eu/legal-content/EN/TXT/PDF/?uri=CELEX:32017R2470\&from=EN (accessed on 1 November 2021).

177. Canada, H. Ultraviolet Light Treatment of Apple Juice/Cider Using the CiderSure $3500 . \quad$ Available online: https:/ / www.canada.ca/en/health-canada/services/food-nutrition/genetically-modified-foods-other-novel-foods/approvedproducts/novel-food-information-ultraviolet-light-treatment-apple-juice-cider-using-cidersure-3500.html (accessed on 1 November 2021). 